\title{
Antifungal, antibacterial and antioxidant properties of Adansonia digitata and Vitex doniana from Bénin pharmacopeia
}

\author{
Latifou LAGNIKA*, Madjid AMOUSSA, Yann ADJOVI and Ambaliou SANNI
}

Laboratory of Biochemistry and Molecular Biology, Faculty of Sciences and Technology, Institute of Applied Biomedical Sciences, University of Abomey-Calavi, 04 BP 0320, Cotonou, Republic of Bénin.

Accepted 15 June, 2012

The dichloromethane, methanol and hydroethanolic extracts from leaves of Vitex doniana and stem bark of Adansonia digitata have been investigated for their antibacterial, antifungal, antioxidant activities and toxicity. The antifungal activity has been investigated against six species of Aspergillus by measuring the mycelial and sporulation inhibitions. The antimicrobial activity was investigated against six Gram positive and Gram negative strains using the microplate dilution method. The phytochemical study was performed on thin layer chromatography and antioxidant activity was measured using 1,1-diphenyl-2-picrylhydrazyl (DPPH) scavenging test. The sporulation inhibition percentage was $70 \%$ while mycelial inhibition was less than $40 \%$. The minimum inhibitory concentration ranged from 0.039 to $2.5 \mathrm{mg} / \mathrm{ml}$. In DPPH radical scavenging assay, the effect on reducing free radicals increased in a dose dependent manner. Three extracts out of six were very active compared to quercetol, with inhibition percentage ranging from 77.39 to $86.55 \%$. The results supported the utilization of these plants in infectious diseases and also showed these plants as good sources for antioxidants.

Key words: Antifungal, antibacterial, antioxidant, Adansonia digitata, Vitex doniana.

\section{INTRODUCTION}

Diseases due to pathogenic bacteria and fungi represent a critical problem to human health and they are one of the main causes of morbidity and mortality worldwide (WHO, 1998). The emergence of pathogens resistant to antibiotics as a result of their excessive use in clinical and veterinary applications represents a serious public health concern (Keymanesh et al., 2009). In the last three decades, pathogenic resistant bacteria caused major health problems throughout the world although the pharmacological industries produced quantities of antibiotics. Unfortunately, the resistance of bacteria and fungi to these drugs is increasingly important. The search for plants with antibacterial and antifungal activity has

${ }^{\star}$ Corresponding author. E-mail: latifkabe@yahoo.fr. Tel: (229) 97604889. gained increasing importance in recent years due to the development of resistance.

On the other hand, it is known that free radicals play a fundamental role in several diseases. The biochemical damages caused by free radicals to cells and tissues, lead to the development of diseases such as arteriosclerosis, high blood pressure, cancer, inflammation, renal failure, liver disease (Gupta et al., 2007). Medicinal plants are largely used either for the prevention, or for the curative treatment of several diseases. Among the properties behind these virtues, the antioxidant activity holds the first place (Trichopoulou et al., 2007; Rahman, 2008). Plants used in traditional medicine may constitute an important source of new biologically active compounds. It is estimated that there are about 2, 500000 species of higher plants and the majority of these plants have not been studied for their pharmacological activities (Ram et al., 2004). According to World Health 
Organization (WHO), 80\% of the world population still relies mainly on substances extract from plants to cure diseases (Kumara et al., 2001).

Vitex doniana, (Verbenaceae) is a tree of 10 to $15 \mathrm{~m}$ (32 to 49 feet) in height, commonly called Fon, or Ewe oyi by traditional healers and plants sellers in Bénin. The leaves consist of 5 sepals. Flowers are white and sometimes stained with purple. Fruits are stone fruits green - dark then black when mature (looking like black olives). $V$. doniana is used by traditional healers alone or in a combination with stem bark of Adansonia digitata to treat diarrhea, leprosy and dysentery (Adjanohoun et al., 1989). The leaves are used as antiseptic and antidiabetic (Muanda et al., 2011). The aerial parts are used in Mali as diuretic, tonifiant, aphrodisiac and bactericide (Ouattara, 2005; Goetz, 2006). A. digitata (Bombacaceae) is called Kpassa, Zuntin, Oshe or Bobodi in Bénin (Adjanohoun et al., 1989). This plant is traditionally used to treat diarrhea and infectious diseases (Kubmarawa et al., 2007). The fibers of the pod are used as decoction to treat amenorrhea. They can be used as a febrifuge, anti-dysenteric and in the treatment of smallpox and measles (Shahat, 2006; Doughari, 2006). The bark of the trunk is used in the treatment of malaria and also used to bath babies to encourage a smooth skin (Adjanohoun et al., 1989; Kristensen and Lykke, 2003).

The aim of the study is to investigate the phytochemical constituents, the antifungal and antibacterial activities using dichloromethane, methanol and hydroethanolic extracts of leaves of $V$. doniana and stem bark of $A$. digitata, against six species of Aspergillus and seven bacteria strains. The antioxidant activity was also performed using 1,1-diphenyl-2-picrylhydrazyl (DPPH) radical scavenging assay. Our results would strengthen the traditional use of these plants and contribute to the acceptance of traditional medicine.

\section{MATERIALS AND METHODS}

The leaves of $V$. doniana and stem bark of $A$. digitata were collected in September 2010 from Ouidah, in the Department of Atlantic, the Southern Commune of Bénin. The collection and identification were carried out by botanists from the University of Abomey-calavi. After identification, the parts collected for each plant were dried for two weeks in laboratory $\left(22^{\circ} \mathrm{C}\right)$ and ground to a fine powder using an electric grinder (Excella mixer grinder).

\section{Extraction of plants material}

Air dried plant material of each species $(100 \mathrm{~g})$ was extracted with dichloromethane $(400 \mathrm{ml})$ at room temperature and after $24 \mathrm{~h}$, filtered through Whatman No. 1 paper. The residue was extracted again twice for $2 \mathrm{~h}$ in the same solvent. The extracts were pooled together. After drying under hood extractor, the same plant residue was then extracted with methanol $(400 \mathrm{ml})$ using the same procedure. In brief, $50 \mathrm{~g}$ of each plant material were also extracted three times with $20 \%$ ethanol for $2 \mathrm{~h}$. The filtrates of each extraction were desiccated under vacuum and the residues were stored in a freezer until use for biological assays.

\section{Phytochemical study}

Phytochemical analysis for major constituents was achieved on thin layer chromatography (TLC) plate (Alugram, Silicagel $60 \mathrm{~F}_{254}$ ) using standard procedures (Wagner and Blat, 2001; Bruneton, 2009). The tests for alkaloids, anthracene derivatives, flavonoids, coumarins, lignans, naphthoquinones, saponins, essential oils, terpenes glycosides, pigments, triterpene and tannins were carried out. Dragendorff, Meyer and iodoplatinate reagents were used for alkaloids detection. Air dried plant material $(1 \mathrm{~g})$ is mixed thoroughly with $1 \mathrm{ml} \mathrm{10 \%}$ ammonia solution and then extracted for 10 min with $5 \mathrm{ml}$ methanol in water bath $\left(50^{\circ} \mathrm{C}\right)$. The mixture was filtered through hydrophilic cotton and then concentrated under vacuum to about $1 \mathrm{ml}$. A volume of $10 \mu \mathrm{L}$ was used for TLC; chromatographic solvents: chloroform/methanol/ammonia 10\% (80:40:15). Alkaloids appear as brown or orange with Dragendorff reagent and blue or brown with iodoplatinate reagent.

The test of anthracene derivatives was also carried out with the filtrate obtained by extracting $0.5 \mathrm{~g}$ of powdered plants for $5 \mathrm{~min}$ on a water bath $\left(40^{\circ} \mathrm{C}\right)$ with $5 \mathrm{ml}$ methanol. A total of $10 \mu \mathrm{L}$ of the filtrate was used for TLC; chromatographic solvents: ethyl acetate/ methanol/water (100:13.5:10). After spraying of $10 \%$ ethanolic potassium hydroxide $(\mathrm{KOH})$, anthracene derivatives appeared as red or yellow spots under UV $365 \mathrm{~nm}$. Intense yellow is also obtained under UV $365 \mathrm{~nm}$ with Natural product/ Polyethylene glycol (NP/PEG). Coumarin was identified by extracting $1 \mathrm{~g}$ sample with $10 \mathrm{ml}$ methanol for $30 \mathrm{~min}$ on the water bath $\left(50^{\circ} \mathrm{C}\right)$. The filtrate is evaporated to about $1 \mathrm{ml}$ and $20 \mu \mathrm{L}$ is used for TLC investigation; chromatographic solvents: ethyl acetate/formic acid/acetic acid/water (100:11:11:26). Coumarin fluoresce pale blue or yellow-brown with $10 \%$ ethanolic $\mathrm{KOH}$ and blue or blue-green with NP/PEG under UV $365 \mathrm{~nm}$.

Essential oils were detected by dissolving $1 \mathrm{~g}$ of powdered plant in $10 \mathrm{ml}$ of dichloromethane for $15 \mathrm{~min}$. The suspension was filtered and the filtrate evaporated to dryness. The residue is dissolved in 1 $\mathrm{ml}$ toluene and $20 \mu \mathrm{L}$ is used for TLC; chromatographic solvents: chloroform/hexane (75:25). Essential oils showed strong blue, green, red and brown coloration after spraying vanillin-sulphuric acid (VS) end heating for $5 \mathrm{~min}$ at $105^{\circ} \mathrm{C}$. Natural product reagent (NP/PEG) was used for the identification of flavonoids. Briefly, $1 \mathrm{~g}$ of powdered plant was extracted with $10 \mathrm{ml}$ of methanol for $5 \mathrm{~min}$ in a water bath at $60^{\circ} \mathrm{C}$ and then filtered. Subsequently, $20 \mu \mathrm{L}$ of filtrate was used for TLC; chromatographic solvents: ethyl acetate/ formic acid/acetic acid/water (100:11:11:26). Flavonoids appear as orange, yellow or yellow-green zones in visible.

For lignans, $1 \mathrm{~g}$ of each powdered plant was extracted with $10 \mathrm{ml}$ methanol by heating on water bath $\left(60^{\circ} \mathrm{C}\right)$ for $10 \mathrm{~min}$. The filtrate was concentrate to $3 \mathrm{ml}$ following evaporation and $20 \mu \mathrm{L}$ was used for TLC; chromatographic solvents: chloroform/methanol/water (70:30:4). For pigments, $1 \mathrm{~g}$ of powdered plant was also extracted by shaking for $15 \mathrm{~min}$ with $6 \mathrm{ml}$ of a mixture of methanol and $25 \%$ $\mathrm{HCl}$ (9:1). Overall, $20 \mu \mathrm{L}$ of the filtrate was used for TLC investigation; chromatographic solvents: ethyl acetate/formic acid/acetic acid/water (100:11:11:26). After spraying vanillinsulphuric acid and heating $\left(5 \mathrm{~min} / 105^{\circ} \mathrm{C}\right)$, lignans show red or brown zones while pigments appears red-violet or blue. Additionally, Liebermann-Burchard reagent (LB) was used for terpene glycosides test. In brief, $1 \mathrm{~g}$ of each sample was extracted for $15 \mathrm{~min}$ with $15 \mathrm{ml}$ methanol on water bath $\left(60^{\circ} \mathrm{C}\right)$. Afterward, 20 $\mu \mathrm{L}$ of filtrate was used for TLC; chromatographic solvents: chloroform/methanol/water (65:25:4). The plate was heated for 5 min at $105^{\circ} \mathrm{C}$. Grey or red-brown spots indicated the presence of terpene glycosides. Furthermore, $1 \mathrm{~g}$ of powdered material was extracted with $10 \mathrm{ml}$ methanol for $15 \mathrm{~min}$ on a water bath $\left(60^{\circ} \mathrm{C}\right) .20$ $\mu \mathrm{l}$ of filtrate is used for TLC and toluene/chloroform/ethanol (40:40:10) for chromatographic solvents. Blue, violet or red color indicated the presence of triterpenes after spraying anisaldehyde sulfuric acid and heating for $5 \mathrm{~min}$ at $105^{\circ} \mathrm{C}$. 

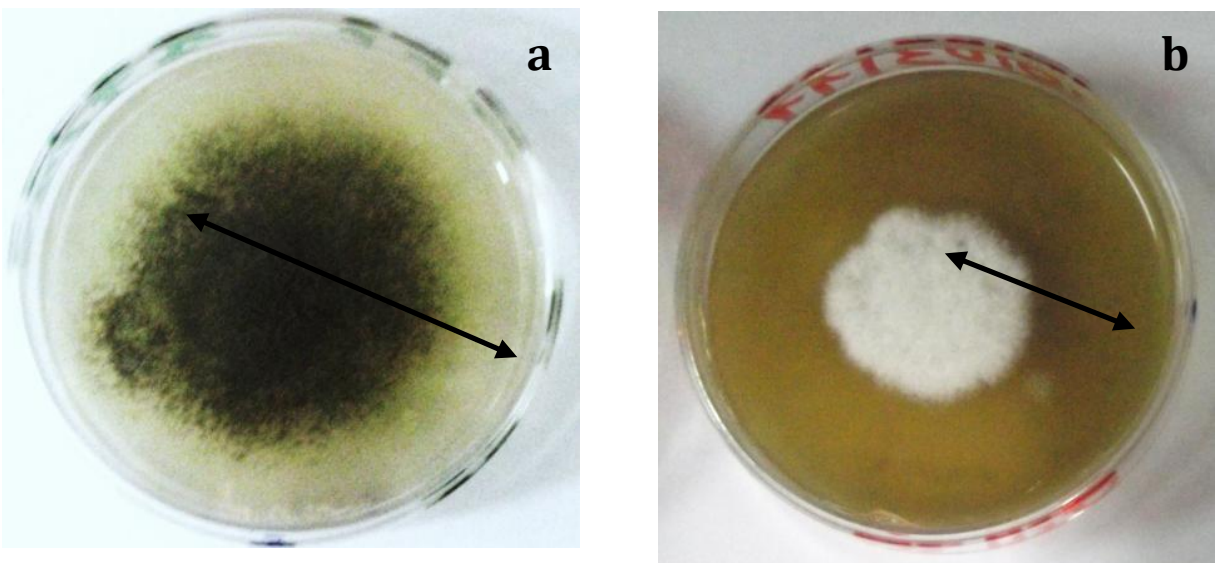

Figure 1. Mycelia development after 5 days in control (potato dextrose agar) and test dish (potato dextrose agar + extract). a: Petri dish with PDA (control); b: Petri dish with PDA + extract $(1 \mathrm{mg} / \mathrm{ml})$.

The detection of naphthoquinones was carried out by extracting 1 $\mathrm{g}$ of each sample with $10 \mathrm{ml}$ methanol for $10 \mathrm{~min}$ on a water bath $\left(50^{\circ} \mathrm{C}\right)$. Next, $30 \mu \mathrm{L}$ of the clear filtrate was used for TLC; chromatographic solvents: toluene/formic acid (99:1). After spraying the plate with $10 \%$ methanolic $\mathrm{KOH}$ reagent, naphthoquinones show red to red-brown color. For saponin identification, $2 \mathrm{~g}$ was extracted by heating for $10 \mathrm{~min}$ on water bath $\left(60^{\circ} \mathrm{C}\right)$ with $10 \mathrm{ml}$ $70 \%$ ethanol. The filtrate is concentrated to $3 \mathrm{ml}$ following evaporation, and $20 \mu \mathrm{L}$ was used for TLC; chromatographic solvents: chloroform/acetic acid/methanol/water (64:32:12:8). Blue, violet or yellow-brown spots were observed after spraying vanillinsulphuric acid (vis). Vanillin-hydrochloric acid reagent was used for tannins detection. A quantity of $10 \mathrm{~g}$ of each powdered sample was extracted twice with $50 \mathrm{ml}$ methanol for 20 min on a water bath $\left(45^{\circ} \mathrm{C}\right)$. The filtrate was taken to dryness under vacuum. Next, $20 \mu \mathrm{L}$ of the extract at $10 \mathrm{mg} / \mathrm{ml}$ was used for TLC; ethyl acetate/methanol/water $(100: 17: 13)$. After heating $\left(5 \mathrm{~min}, 105^{\circ} \mathrm{C}\right)$, tannins appear red color.

\section{Antifungal assay}

Six fungi species, Aspergillus flavus CMBB75, A. parasiticus CMBB20, $A$. ochraceus CMBB91, $A$. nidulans CMBB90, $A$. terreus CMBB94 and $A$. fumigatus CMBB89, were obtained from the Laboratory of Biochemistry and Molecular Biology of the University of Abomey-calavi. These are the most common disease-causing fungi of vegetables, animals and humans. Each fungus was cultured on potato dextrose agar medium (PDA). Antifungal activity was evaluated on mycelia development and sporulation stages as described by Dohou et al. (2004). The mixture of sterilized potato dextrose agar $(10 \mathrm{ml})$ and $10 \mathrm{~g}$ of each extract were poured in sterile disposable petri dishes. After solidification, 100 spores prepared in Tween 25\% was deposited on the PDA and the petri dishes were left at $25^{\circ} \mathrm{C}$ for 5 days. Each assay was run in triplicate. Two petri dishes without extract were used as controls (Figure 1). The inhibition percentage (PI) of extracts was determined according to the formula below:

$\mathrm{PI}(\%)=\frac{\mathrm{A}-\mathrm{B}}{\mathrm{A}} \times 100$

Where $\mathrm{PI}$ is the inhibition percentage; $\mathrm{A}$ is the average diameter of the mycelia or estimated number of spores of control; $B$ is the average diameter of the mycelia or estimated number of spores of tested dishes.

\section{Antibacterial activity}

The used bacteria organisms for antibacterial activity were Escherichia coli CIP 53126, Staphylococcus aureus ATCC 6538, Enterococcus faecalis ATCC 29212, Pseudomonas aeruginosa CIP82118, Salmonella abony CIP 8039, Staphylococcus aureus Methicillin Resistant (SARM) and Staphylococcus epidermidis obtained from Laboratoire de Biophotonique et Pharmacologie, University of Strasbourg, France.

\section{Growth inhibition effect of extracts at $10 \mathrm{mg} / \mathrm{ml}$}

The aim of this method was to eliminate the extracts, which at 10 $\mathrm{mg} / \mathrm{ml}$ do not inhibit the growth of bacteria (Eloff, 1998). The extracts were reconstituted to a concentration of $20 \mathrm{mg} / \mathrm{ml}$ in acetone/Muller Hinton broth culture. A volume of $100 \mu \mathrm{L}$ of each extract $(20 \mathrm{mg} / \mathrm{ml})$ was introduced in triplicate microplate already seeded with $100 \mu \mathrm{L}$ of the Muller Hinton broth culture inoculums $\left(10^{6} \mathrm{CFU} / \mathrm{ml}\right)$ of the tested bacteria. The microplate was incubated at $37^{\circ} \mathrm{C}$. After $18 \mathrm{~h}$ of incubation, $40 \mu \mathrm{L}$ of $0.2 \mathrm{mg} / \mathrm{ml}$ solution of $p$ iodonitrotetrazolium (Sigma Aldrich) were added to each well and microplate was incubated at $37^{\circ} \mathrm{C}$. Finally, after $30 \mathrm{~min}$, the color change (extract color to red) of mix in each well was examined to select actives extracts. Active extract do not change color.

\section{Minimum inhibitory concentration (MIC)}

MIC values of active extracts were determined by slightly modified serial dilution microplate bioassay using specific dye $p$ iodonitrotetrazolium violet as an indicator of growth (Eloff, 1998). Active extracts were reconstituted to $20 \mathrm{mg} / \mathrm{ml}$ with a mixture of acetone/Muller Hinton ( $\mathrm{v} / \mathrm{v})$. MIC was determined by two-fold serial dilutions of extracts beyond the level where no inhibition of growth of microorganisms were observed. Next, $100 \mu \mathrm{L}$ of Muller Hinton broth culture of bacteria $\left(10^{6} \mathrm{CFU} / \mathrm{ml}\right)$ was added to each well which contains extract. The microplates were incubated at $37^{\circ} \mathrm{C}$. After 18 h, $40 \mu \mathrm{L}$ of $p$-iodonitrotetrazolium $(0.2 \mathrm{mg} / \mathrm{ml})$ solution in water were added to each well and the microplates were incubated at $37^{\circ} \mathrm{C}$. 
Table 1. Phytochemical analysis of $V$. doniana and A. digitata.

\begin{tabular}{|c|c|c|c|c|}
\hline \multirow{3}{*}{ Phytochemical } & \multicolumn{4}{|c|}{ Result } \\
\hline & \multicolumn{2}{|c|}{ Color obtained } & \multicolumn{2}{|c|}{$+/-$} \\
\hline & Vd & Ad & Vd & Ad \\
\hline Alkaloid & $\mathrm{nc}$ & nc & - & - \\
\hline Coumarin & $\mathrm{nc}$ & $\mathrm{nc}$ & - & - \\
\hline Anthracene derivatives & Yellow & $\mathrm{nc}$ & + & - \\
\hline Flavonoids & Yellow & $\mathrm{nc}$ & + & - \\
\hline Essential oils & Green & nc & + & - \\
\hline Lignans & $\mathrm{nc}$ & $\mathrm{nc}$ & - & - \\
\hline Naphthoquinones & $\mathrm{nc}$ & $\mathrm{nc}$ & - & - \\
\hline Pigments & Red-violet & Blue-violet & + & + \\
\hline Saponin & $\mathrm{nc}$ & $\mathrm{nc}$ & - & - \\
\hline Tannins & Red & Red & + & + \\
\hline Terpene glycosides & Red-brown & Red-brown & + & + \\
\hline Triterpenes & Red & $\mathrm{nc}$ & + & - \\
\hline
\end{tabular}

-: Absent; +: present; nc: not colored, Vd: Vitex doniana; Ad: Adansonia digitata.

After $1 \mathrm{~h}$ of incubation, the MIC values were recorded. The total activity (TA) values of each extract were determined by dividing the MICs with the quantity extracted from $1 \mathrm{~g}$ of the plant material (Eloff, 2004).

\section{Quantitative antioxidant activity}

The quantitative antioxidant activity was determined according to the method described previously by Velazquez et al. (2003). Three stock solutions of extracts $(300 ; 30$ and $3 \mu \mathrm{g} / \mathrm{ml})$ were prepared and tested in the final concentrations of 100,10 and $1 \mu \mathrm{g} / \mathrm{ml}$. Next, 750 $\mu \mathrm{L}$ of stock solution of each extract and $1500 \mu \mathrm{L}$ of a $2 \%$ solution of $\mathrm{DPPH}$ in methanol were introduced into dry and sterile tubes. For each concentration a blank and a negative control are prepared. The Blank consists of $750 \mu \mathrm{L}$ of extract and $1500 \mu \mathrm{L}$ of methanol. The negative control consists of $1500 \mu \mathrm{L}$ of the solution of DPPH $(2 \%)$ and $750 \mu \mathrm{L}$ of methanol. Each test was done in triplicate and quercetol was used as positive control. The test tubes were incubated in dark at room temperature. After $20 \mathrm{~min}$, the optical density of each mixture was measured at $517 \mathrm{~nm}$. The inhibitory percentage of $\mathrm{DPPH}$, which means the antioxidant activity of extracts, was calculated as follows (Schmeda-Hirschmann et al., 2003):

$\%$ Inhibition $=\left[1-\left(A_{S}-A_{B}\right) / A_{C}\right] \times 100$

Where \% Inhibition is the inhibitory percentage of DPPH; $A_{S}$ is the optical density (OD) of the sample; $A_{B}$ is the OD of blank; $A_{C}$ is the $\mathrm{OD}$ of the control.

\section{Brine shrimp lethality bioassay (Artemia salina)}

This assay was performed as described by Kawsar et al. (2008) and Meyer (1982). To obtain mature naupli larva, the eggs of brine shrimp were hatched in normal seawater for $72 \mathrm{~h}$. The stock solution of each extract $(3 \mathrm{mg} / \mathrm{ml})$ was obtained by dissolving $15 \mathrm{mg}$ in $200 \mu \mathrm{L}$ ethanol and $4.80 \mathrm{ml}$ of seawater. Then, $1 \mathrm{ml}$ of seawater containing 15 living naupli was added to $1 \mathrm{ml}$ of extracts. Six concentrations ranging from 1.5 to $0.075 \mathrm{mg} / \mathrm{ml}$, obtained by a twofold dilution of stock solution, were tested. Each experiment was done in triplicate and control was prepared using only seawater plus 15 living naupli. Survivors were counted after $24 \mathrm{~h}$ and the death at each concentration were determined. The percentage of lethality of the brine shrimp was then calculated.

\section{RESULTS}

\section{Phytochemical results}

The phytochemical screening of $V$. doniana and $A$. digitata on thin layer chromatography (TLC) has been performed. TLC of leaves of $V$. doniana revealed the presence of flavonoids, anthracene derivatives, essential oil, pigments, tannins, terpenes glycosides and triterpenes, while the bark of $A$. digitata revealed the presence of tannins, pigments and terpene glycosides (Table 1).

\section{Antifungal assay}

Six extracts from two plants used in Benin folk medicine were tested for their antifungal activity on mycelial growth and sporulation of fungi. The results are compiled in Tables 2 and 3. The inhibitory percentage (IP) of extracts against sporulation of the six species of Aspergillus ranged from 20 to $99.85 \%$. Thirty (30) assays out of 36 showed an IP values superior to $60 \%$. The most interesting activity was obtained with $A$. fumigatus with an IP values from 70.7 to $99.85 \%$. A. flavus, $A$. fumigatus, $A$. nidulans and $A$. ochraceus were the most sensible fungi for extracts. Contrary to sporulation, the inhibition percentage (IP) of extracts against mycelia development ranged from 2.98 to $53.42 \%$. Only dichloromethane extract of $V$. doniana inhibited mycelia development of $A$. terreus with inhibition percentage value of $53.42 \%$. The other extracts showed weaker results. 
Table 2. Inhibition effect of extracts against sporulation of fungi.

\begin{tabular}{lcccccc}
\hline \multirow{2}{*}{ Extract } & \multicolumn{6}{c}{ Inhibition percentage of sporulation (\%) } \\
\cline { 2 - 7 } & A. flavus & A. parasiticus & A. terreus & A. ochraceus & A. nidulans & A. fumigatus \\
\hline $\mathrm{Vd} \mathrm{DM}$ & $68 \pm 0,06$ & $77.85 \pm 0.11$ & $92.32 \pm 0.06$ & $86.81 \pm 0.14$ & $83.38 \pm 0.02$ & $96.4 \pm 0.006$ \\
$\mathrm{Vd} \mathrm{Me}$ & $94.4 \pm 0.01$ & $60.4 \pm 0.08$ & $74.28 \pm 0.05$ & $86.44 \pm 0.18$ & $84.38 \pm 0.019$ & $70.7 \pm 0.03$ \\
$\mathrm{Vd} \mathrm{H} \mathrm{H}_{2} \mathrm{O}$ & $88 \pm 0.04$ & $58.11 \pm 0.37$ & $96.16 \pm 0.00$ & $72.74 \pm 0.32$ & $91.84 \pm 0.014$ & $99.48 \pm 0.001$ \\
$\mathrm{Ad} \mathrm{DM}$ & $20 \pm 0.11$ & $44.08 \pm 0.29$ & $69.82 \pm 0.02$ & $92.88 \pm 0.07$ & $88.33 \pm 0.015$ & $98.9 \pm 0.001$ \\
$\mathrm{Ad} \mathrm{Me}$ & $94 \pm 0.02$ & $35.71 \pm 0.28$ & $60.71 \pm 0.13$ & $57.33 \pm 0.10$ & $89 \pm 0.008$ & $99.85 \pm 0.000$ \\
$\mathrm{Ad} \mathrm{H} \mathrm{H}_{2} \mathrm{O}$ & $95 \pm 0.01$ & $51.53 \pm 0.08$ & $86.07 \pm 0.05$ & $91.55 \pm 0.07$ & $95.88 \pm 0.007$ & $97.26 \pm 0.001$ \\
\hline
\end{tabular}

Vd: Vitex doniana; Ad: Adansonia digitata; DM: dichloromethane; $\mathrm{Me}$ : methanol; $\mathrm{H}_{2} \mathrm{O}$ : water/ethanol.

Table 3. Inhibition effect of extracts against Aspergillus mycelia development.

\begin{tabular}{lcccccc}
\hline \multirow{2}{*}{ Extract } & \multicolumn{5}{c}{ Inhibition percentage of mycelia development (\%) } \\
\cline { 2 - 7 } & A. flavus & A. parasiticus & A. terreus & A. ochraceus & A. nidulans & A. fumigatus \\
\hline Vd DM & $21.42 \pm 0.03$ & $47 \pm 0.042$ & $53.42 \pm 0.0$ & $41.37 \pm 0.028$ & $7.46 \pm 0.02$ & $11.11 \pm 0.02$ \\
Vd Me & $38.37 \pm 0.00$ & $40 \pm 0.014$ & $39.72 \pm 0.0$ & $44.82 \pm 0.026$ & $7.46 \pm 0.01$ & $20 \pm 0.025$ \\
Vd H ${ }_{2} \mathrm{O}$ & $16.32 \pm 0.03$ & $20 \pm 0.042$ & $34.24 \pm 0.0$ & $48.27 \pm 0.001$ & $41.79 \pm 0.0$ & $15.55 \pm 0.08$ \\
$\mathrm{Ad} \mathrm{DM}$ & $18.36 \pm 0.02$ & $36 \pm 0.014$ & $47.94 \pm 0.0$ & $37.93 \pm 0.030$ & $2.98 \pm 0.04$ & $8.88 \pm 0.065$ \\
$\mathrm{Ad} \mathrm{Me}$ & $22.45 \pm 0.00$ & $32 \pm 0.014$ & $39.72 \pm 0.0$ & $41.37 \pm 0.028$ & $16.41 \pm 0.0$ & $22.22 \pm 0.00$ \\
$\mathrm{Ad} \mathrm{H} \mathrm{H}_{2} \mathrm{O}$ & $22.49 \pm 0.10$ & $22 \pm 0.028$ & $42.46 \pm 0.0$ & $39.65 \pm 0.043$ & $16.41 \pm 0.0$ & $15.55 \pm 0.03$ \\
\hline
\end{tabular}

Vd: Vitex doniana; Ad: Adansonia digitata; DM: dichloromethane; Me: methanol; $\mathrm{H}_{2} \mathrm{O}$ : water/ethanol.

Table 4: Antibacterial effect of extracts at $10 \mathrm{mg} / \mathrm{ml}$.

\begin{tabular}{|c|c|c|c|c|c|c|}
\hline \multirow{3}{*}{$\begin{array}{l}\text { Data } \\
\text { Organism }\end{array}$} & \multicolumn{6}{|c|}{ Growth inhibition effect of extract at $10 \mathrm{mg} / \mathrm{ml}$} \\
\hline & \multicolumn{3}{|c|}{ Vitex doniana } & \multicolumn{3}{|c|}{ Adansonia digitata } \\
\hline & DM & $\mathrm{MeOH}$ & $\mathrm{H}_{2} \mathrm{O} / \mathrm{EtOH}$ & DM & $\mathrm{MeOH}$ & $\mathrm{H}_{2} \mathrm{O} / \mathrm{EtOH}$ \\
\hline E. coli (CIP53126) & + & + & + & + & + & + \\
\hline S. aureus(ATCC6538) & - & - & - & - & - & - \\
\hline E. faecalis (ATCC29212) & + & + & + & + & - & - \\
\hline P. aeruginosa (CIP82118) & - & - & + & - & + & + \\
\hline S. abony (CIP8039) & + & + & + & + & + & + \\
\hline S. aureus methicillin résistant & - & - & + & - & - & - \\
\hline S. epidermidis & - & - & - & - & - & - \\
\hline
\end{tabular}

DM: dichloromethane; $\mathrm{MeOH}$ : methanol; $\mathrm{H}_{2} \mathrm{O} / \mathrm{EtOH}$ : Water/ethanol; -: inhibition; +: no inhibition.

\section{Antibacterial activity}

\section{Growth inhibition effect of extracts at $10 \mathrm{mg} / \mathrm{ml}$}

The results (Table 4) showed that tested bacteria were sensible to extracts at different levels. The aim of this assay was to eliminate the extracts that did not inhibit the growth of bacteria at $10 \mathrm{mg} / \mathrm{ml}$. All extracts inhibited the growth of $S$. aureus; $S$. aureus methicillin resistant (SARM) and $S$. epidermidis. The dichloromethane and methanol extracts of both plants and hydroalcholic extract of $A$. digitata were the most active extracts by inhibiting the growth of four strains out of seven (4/7). The MIC of active extracts was determined as shown in Table 5 . The results showed that antibacterial activity of $V$. doniana extracts was higher than $A$. digitata extracts. The MIC values of $V$. doniana ranged from 0.039 to $2.5 \mathrm{mg} / \mathrm{ml}$.

In general, all extracts inhibited one or more microorganisms. The dichloromethane extract of $V$. doniana was the most effective against $S$. aureus methicillin resistant (SARM) with MIC value of $39 \mu \mathrm{g} / \mathrm{ml}$. The methanolic and hydroethanolic extracts of $V$. doniana were also active against SARM with MIC values of 78 $\mu \mathrm{g} / \mathrm{ml}$. S. aureus methicillin resistant was found to be 
Table 5. MIC values $(\mathrm{mg} / \mathrm{ml})$ and the total activity $(\mathrm{ml})$ of extracts.

\begin{tabular}{|c|c|c|c|c|c|c|}
\hline \multirow{3}{*}{$\begin{array}{ll}\text { Species } & \\
\text { organism } & \text { Extract }\end{array}$} & \multicolumn{6}{|c|}{ Minimum inhibitory concentration ( $\mathrm{mg} / \mathrm{ml})$} \\
\hline & \multicolumn{3}{|c|}{ Vitex doniana } & \multicolumn{3}{|c|}{ Adansonia digitata } \\
\hline & DM & $\mathrm{MeOH}$ & $\mathrm{H}_{2} \mathrm{O} / \mathrm{EtOH}$ & DM & $\mathrm{MeOH}$ & $\mathrm{H}_{2} \mathrm{O} / \mathrm{EtOH}$ \\
\hline S. aureus (ATCC6538) & 1.25 & 0.312 & 1.25 & $>2.5$ & 1.25 & 2.5 \\
\hline E. faecalis (ATCC29212) & na & na & na & na & 1.25 & 0.625 \\
\hline P. aeruginosa (CIP82118) & $>2.5$ & 2.5 & na & $>2.5$ & na & na \\
\hline S. aureus methicillin resistant & 0.039 & 0.078 & na & 0.156 & 0.078 & 0.078 \\
\hline S. epidermidis & 2.5 & 0.078 & nd & $>2.5$ & 1.25 & nd \\
\hline Extract from $1 \mathrm{~g}(\mathrm{mg})$ & 17.94 & 108.37 & 117.5 & 4.5 & 52 & 111.63 \\
\hline \multicolumn{7}{|l|}{ Total activity (ml) } \\
\hline S. aureus (ATCC6538) & 14.25 & 346.78 & 93.98 & $>1.8$ & 41.6 & 44.66 \\
\hline E. faecalis (ATCC29212) & - & - & - & - & 41.6 & 178.6 \\
\hline P. aeruginosa (CIP82118) & $>7.2$ & 42.54 & - & $>1.8$ & - & - \\
\hline S. aureus methicillin resistant & 459.9 & 1389.38 & - & 28.84 & 666.66 & 1431.16 \\
\hline S. epidermidis & 7.2 & 173.4 & nd & $>1.8$ & 41.6 & nd \\
\hline
\end{tabular}

DM: dichloromethane; $\mathrm{MeOH}$ : methanol; $\mathrm{H}_{2} \mathrm{O} / \mathrm{EtOH}$ : Water/ethanol; M: Meticillin; na: not actif; nd: not determined

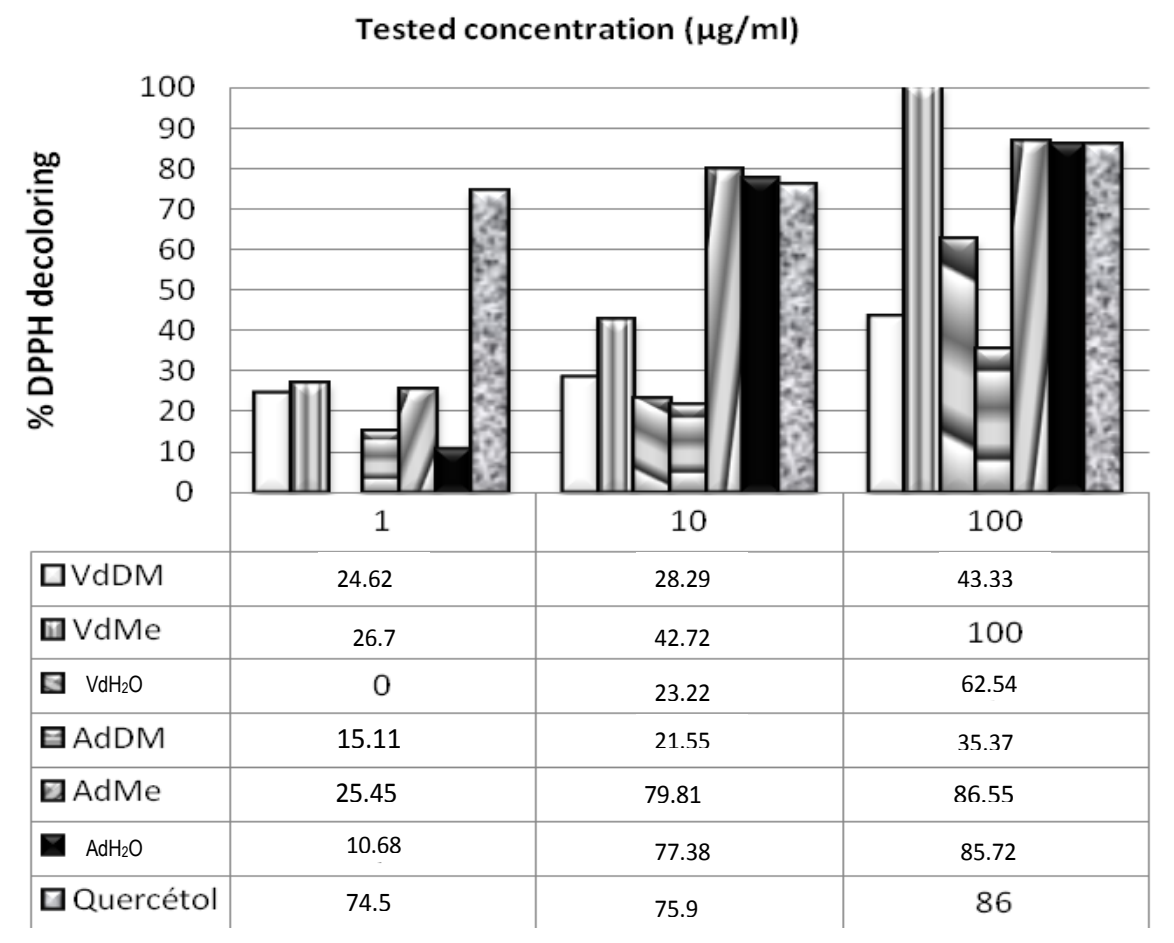

Figure 2. DPPH free radical scavenging activity of extracts.

more sensitive among the tested bacteria while $E$. faecalis the most resistant. The highest total activity was obtained with methanol extract of $V$. doniana and hydroethanolic extract of $A$. digitata, the most interesting with total activity values of $1389.3 \mathrm{ml}$ and $1431.16 \mathrm{ml}$, respectively (Table 5).

\section{Quantitative antioxidant activity}

Figure 2 shows the antioxidant activity of extracts expressed as inhibition percentage (\%IP) of DPPH radical in comparison to the positive control (Quercetol). The scavenging activity of all extracts on the DPPH 
Table 6. Artemia salina lethality assay of extracts.

\begin{tabular}{llcc}
\hline Species & Extract & $\mathbf{D L}_{50}$ & $\mathbf{R}^{\mathbf{2}}$ \\
\hline \multirow{3}{*}{ Vitex doniana } & $\mathrm{DM}$ & 6.27 & 0.875 \\
& $\mathrm{MeOH}$ & 54.81 & 0.428 \\
& $\mathrm{H}_{2} \mathrm{O} / \mathrm{EtOH}$ & 5.69 & 0.862 \\
& & & \\
Adansonia digitata & $\mathrm{DM}$ & $\mathrm{nd}$ & $\mathrm{nd}$ \\
& $\mathrm{MeOH}$ & 5.68 & 0.771 \\
& $\mathrm{H}_{2} \mathrm{O} / \mathrm{EtOH}$ & 11.14 & 0.713 \\
\hline
\end{tabular}

DM: dichloromethane; $\mathrm{MeOH}$ : methanol; $\mathrm{H}_{2} \mathrm{O} / \mathrm{EtOH}$ : water/ethanol; nd: not determined.

radical was found to be strongly dependent on the extract concentration. At $1 \mu \mathrm{g} / \mathrm{ml}$, all extracts showed weak activity with IP values ranging from 0.00 to $26.70 \%$. Moreover, at $10 \mu \mathrm{g} / \mathrm{ml}$, the most interesting activity was obtained with methanol $(79.81 \%)$ and hydroethanolic (77.39\%) extracts of $A$. digitata. These results compared favorably with that of quercetol with an IP value of $75.9 \%$. At $100 \mu \mathrm{g} / \mathrm{ml}$, four extracts out of six showed interesting activity (62.24-100\%) with IP values higher or comparable for quercetol (86\%).

\section{A. salina toxicity assay}

Brine shrimp lethality test results are showed in Table 6 . Figure 3 shows the toxicity curves obtained for all extracts. The $\mathrm{LC}_{50}$ values of tested extracts ranged between 5.68 and $54.81 \mathrm{mg} / \mathrm{ml}$. Hydroethanolic extract of $V$. doniana and methanol extract of $A$. digitata were the most toxic on the shrimps with $L_{50}$ values of 5.69 and $5.68 \mathrm{mg} / \mathrm{ml}$, respectively. The highest $\mathrm{LC}_{50}$ was exhibited by methanol extract of $V$. doniana $(54.81 \mathrm{mg} / \mathrm{ml})$.

\section{DISCUSSION}

The development of drug resistance in human pathogens against commonly used antibiotics and antifungal has necessitated a search for new antimicrobial substances. Higher plants produce diverse secondary metabolites with different biological activities. These natural compounds may be a source of compounds with antimicrobial effects and therefore possible candidates for the development of new antifungal agents (Barrett, 2002; Abad et al., 2007). In this study, two species were evaluated for qualitative determination of major phytoconstituents. They exhibited different kinds of secondary metabolites. $V$. doniana revealed the presence of flavonoids, anthracene derivatives, essential oil, pigments, tannins, terpenes glycosides and triterpenes. Previous chemical investigations on ethanolic and aqueous extracts indicated the presence of saponins, tannins, anthraquinones, terpenoids and flavonoids (Agbafor and
Nwachukwu, 2011; Kubmarawa et al., 2007). Similarities are observed between the results, particularly the presence of tannins and flavonoids. A. digitata revealed the presence of tannins, pigments and terpene glycosides. Tannins, phlobatannins, terpenoids, cardiac glycosides and saponins were also found to be present (Masola et al., 2009; Lim et al., 2006).

In this study, methanol and hydroethanol extracts showed interesting antibacterial (0.039 - $2.5 \mathrm{mg} / \mathrm{ml})$ and/or antifungal (IP up to $99.85 \%$ ) activity by inhibiting one or more microorganisms. Our results were comparable to those obtained by Agbafor and Nwachukwu (2011) with methanol extract of $V$. doniana. Previous investigation on different extracts of $A$. digitata showed weak results with inhibitory percentage ranging from 18 to 78 at $500 \mu \mathrm{g} / \mathrm{ml}$ (Oloyede et al., 2010). The interesting antimicrobial activity against the tested bacteria could be due to the presence of tannins, and flavonoids as these have previously been reported to possess antimicrobial activities (Masola et al., 2008; Finnermore et al., 1988; Erah et al., 1996; Ishida et al., 2009). Tannins are known antimicrobial agents that could inhibit the growth of microorganisms by precipitating the microbial protein and thus depriving them of nutritional proteins needed for their growth and development (Obasi Nnamdi et al., 2010). Flavonoids have been also reported to possess many useful properties, including antimicrobial (Havsteen, 1983), antifungal and antioxidant activities (Cushnie and Lamb, 2005). In our study, tannins and flavonoids were detected in methanol and hydro-ethanol extracts. This could explain the antimicrobial activity of the extracts.

We also observed that the antifungal activity of extracts is more marked on the inhibition of the sporulation than on the mycelia development of the fungi. The higher inhibition percentage of methanol and hydroethanol extracts could be due to the presence of tannins and flavonoids. It has been reported that flavonoids have the ability to inhibit spore germination of plant pathogens (Harborne and Williams, 2000), and tannins inhibit the germ-tube formation and stimulus of phagocytosis by macrophages (Ishida et al., 2006), and extracellular microbial enzymes through inhibition of oxidative phosphorylation (Scalbert, 1991). Galangin, a flavonol, has been shown to have inhibitory activity against Aspergillus tamarii, A. flavus, Cladosporium sphaerospermum, Penicillium digitatum and Penicillium italicum, Candida neoformans (Ishida et al., 2009; Afolayan and Meyer, 1997). This could explain the results obtained on inhibition of sporulation.

The results from the present investigation suggested that $A$. digitata and $V$. doniana have interesting activity by inhibiting DPPH radical. Our results were comparable to those obtained by Muanda et al. (2011) with methanol extract of $V$. doniana. Previous investigation on different extracts of $A$. digitata showed higher activity with inhibitory percentage ranging from 18 to 78 at $500 \mu \mathrm{g} / \mathrm{ml}$ 


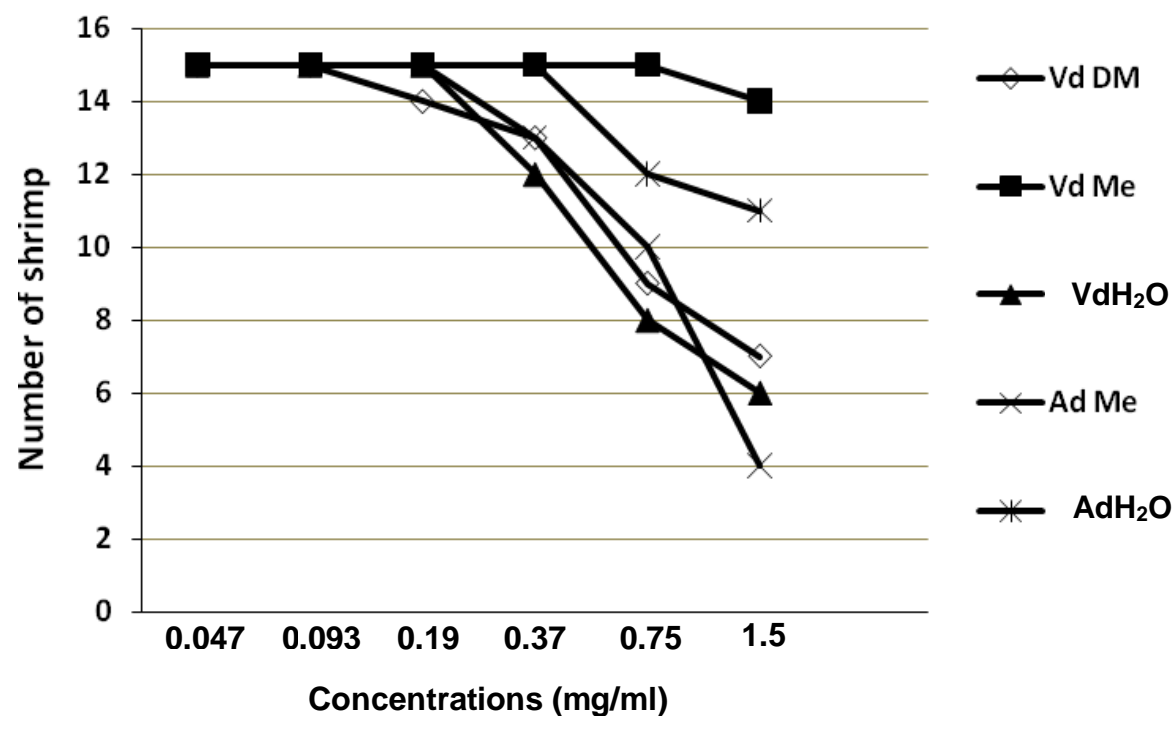

Figure 3. Lethal effect of extracts on brine shrimp nauplii at different concentrations.

(Oloyede et al., 2010). The scavenging activity obtained here is dose dependent. It has been shown that the scavenging effects on the DPPH radical increase with increasing concentration of samples and standards to a certain extent (Motalleb et al., 2005). The antioxidant activity obtained here could be due to the presence of flavonoids and tannins. These chemical compounds have been reported to possess antioxidant activity and several reports indicated that the antioxidant potential of medicinal plants may be related to the concentration of their phenolic compounds which include phenolic acids, flavonoids, anthocyanins and tannins (Djeridane et al., 2006; Wong et al., 2006). These species could contain compounds with strong radical scavenging activity and could possess therapeutic effects such as inflammatory diseases and cardiovascular protection.

Antioxidants are also believed to provide protection against cancer (Anani et al., 2000; Ames, 1983). Several epidemiological studies suggest that plants rich in antioxidants play a protective role in health and against diseases (Muanda et al., 2011) and their consumption lowered the risk for cancer, heart disease, high blood pressure and stroke (Vinson et al., 2001; Wolfe et al., 2003). It is also interesting to note that preliminary toxicity test against $A$. salina showed that $\mathrm{LC}_{50}$ of all extract are superior to most of the concentrations of extract which inhibits studied pathogens. According to the results previously described by Zakaria et al. (2007), we concluded that all tested extracts exhibited very low or no toxicity, giving $\mathrm{LC}_{50}$ values higher than $100 \mu \mathrm{g} / \mathrm{ml}$.

Therefore, the demonstration of antibacterial, antifungal, antioxidant activities and low toxicity of methanol and hydroethanolic extracts provides the scientific basis for the use of these plants in traditional medicine, since most traditional medicine use water and alcohol as their solvent in which the decoctions are prepared.

\section{Conclusion}

All the extracts showed various degrees of biological activity on the tested pathogens. The chance to find compounds with antifungal, antimicrobial activities was more apparent in the two species. These findings give a scientific basis to the traditional uses of $A$. digitata and $V$. doniana.

\section{ACKNOWLEDGEMENTS}

The authors sincerely thank traditional practitioners from Ouidah region. Helpful work of botanist, Dr Yédomonhan from Herbier National of University of Abomey-calavi, is highly appreciated.

\section{REFERENCES}

Abad MA, Ansuategui M, Bermejo P (2007). Active antifungal from natural sources. Arkivoc, pp. 116-145.

Adjanohoun EJ, Adjakidjè V, Ahyi MRA, Akeassi L, Akoegninou A d'Almeida J (1989). Médecine traditionnelle et pharmacopée. Contribution aux études ethnobotaniques et floristiques en République du Bénin. Paris, Agence de Coopération Culturelle et Technique, p. 339.

Afolayan AJ, Meyer JJ (1997). The antimicrobial activity of 3,5,7trihydroxyflavone isolated from the shoots of Helichrysum aureonitens. J. Ethnopharmacol. 57:177-181.

Agbafor KN, Nwachukwu N (2011). Phytochemical Analysis and Antioxidant Property of Leaf Extracts of Vitex doniana and Mucuna pruriens. Biochem. Res. Int., 2011.

Ames BM (1983). Dietary carcinogens and anticarcinogens: oxygen radicals and degenerative diseases. Science 221:1256-1263.

Anani K, Hudson JB, de Souza C, Akpagana K, Tower GHN, Amason 
JT, Gbeassor M (2000). Investigation of medicinal plants of Togo for antiviral and antimicrobial activities. J. Pharm. Biol. 38:40-45.

Barrett D (2002). From natural products to clinically useful antifungals. Biochem. Bioph. Acta 1587:224-233.

Bruneton J (2009). Pharmacognosie, Phytochimie, Plantes médicinales. TEC DOC., 4th edition, Paris France, p. 456.

Cushnie TP, Lamb AJ (2005). Antimicrobial activity of flavonoids. Int. J. Antimicrob. Ag. 26:343-356.

Djeridane A, Yousfi M, Nadjemi B, Boutassouna D, Stocker P, Vidal N (2006). Antioxidant activity of some Algerian medicinal plants extracts containing phenolic compounds. Food Chem. 4:654-660.

Dohou N, Yamni K, Badoc A, Douira A (2004). Activité antifongique d'extraits de Thymelaea lythroides sur Trois champignons pathogènes du riz. Bull. Soc. Pharm. 143:31-38.

Doughari JH (2006). Antimicrobial activity of Tamarindus indica Linn. Trop. J. Pharm. Res. 5:597-603.

Eloff JN (1998). A sensitive and quick method to determine the minimal inhibitory concentration of plant extracts for bacteria. Planta Med. 64:711-713.

Eloff JN (2004). Quantification the bioactivity of plant extracts during screening and bioassay guided fractionation. Phytomedicine 11:370371.

Erah PO, Osuide GE, Omogbai EKI (1996). Hypoglycaemic effect of the extract of Solenostemon monostachys (P. Beauv) leaves. J. West Afr. Pharm. 10:21- 27.

Finnermore H, Cooper JM, Stanley MB, Cobcroft JH, Harris LJ (1988). J. Soc. Chem. Ind. 57:162-169.

Goetz P (2006). Traitement des troubles de la libido masculine. Phytothér. Clinique 1:9-14.

Gupta M, Mazumder UK, Gomathi P (2007). Evaluation of antioxidant and free radical scavenging activities of Plumeria acuminate leaves. J. Biol. Sci. 7:1361-1367.

Harborne JB, Williams CA (2000). Advances in flavonoid research since 1992. Phytochemistry 55:481-504.

Havsteen B (1983). Flavonoids, a class of natural products of high pharmacological potency. Biochem. Pharmacol. 32:1141-1148.

Ishida K, Mello JC, Cortez DA, Dias Filho BP, Ueda-Nakamura T, Nakamura CV (2006). Influence of tannins from Stryphnodendron adstringens on growth and virulence factors of Candida albicans. J. Antimicrob. Chemother. 58:942-949.

Ishida K, Rozental S, Mello JC, Nakamura CV (2009). Activity of tannins from Stryphnodendron adstringens on Cryptococcus neoformans: effects on growth, capsule size and Pigmentation. Ann. Clin. Microb. Antimicrob. 8:29.

Kawsar SMA, Huq E, Nahar N (2008). Cytotoxicity Assessment of the aerial parts of Macrotyloma uniflorum Limm. Int J. Pharm. 4:297-300.

Keymanesh K, Hamedi J, Moradi S, Mohammadipanah F, Sardari S (2009). Antibacterial, antifungal and toxicity of rare Iranian plants. Int. J. Pharm. 5:82-85.

Kristensen M, Lykke AM (2003). Informant-based valuation of use and conservation preferences of savanna trees in Burkina Faso. Econ. Bot. 57(2):203-217.

Kubmarawa D, Ajoku GA, Enwerem NM, Okorie DA (2007). Preliminary phytochemical and antimicrobial screening of 50 medicinal plants from Nigeria. Afr. J. Biotechnol., 6: 1690-1696.

Kumara PD, Jayawardane GL, Aluwihare AP (2001). Complete colonic duplication in an infant. Ceylon Med. J. 46:69-70.

Lim SH, Darah I, Jain K (2006). Antimicrobial activities of tannins extracted from rhizophora apiculata barks. J. Trop. For. Sci. 18:5965.
Masola SN, Mosha RD, Wambura PN (2008). Assessment of antimicrobial activity of crude extracts of stem and root barks from Adansonia digitata (Bombacaceae) (African baobab). Afr. J. Biotechnol. 8:5076-5083.

Meyer BN, Ferrigni NR, Putnam JE, Jacobsen LB, Nichols DE, McLaughlin JL (1982). Brine shrimp: A convenient general bioassay for active plants constituents. Planta Med. 45:31-34.

Motalleb G, Hanachi P, Kua SH, Fauziah O, Asmah R (2005). Evaluation of phenolic content and total antioxidant activity in Berberis vulgaris fruits extract. J. Biol. Sci. 5:648-653.

Muanda F, Kone D, Dicko A, Soulimani R, Younos C (2011). Phytochemical Composition and Antioxidant Capacity of Three Malian Medicinal Plant Parts. Evid-Based. Compl. Alt. Med. 8 p.

Obasi Nnamdi L, Egbuonu ACC, Ukoha PO, Ejikeme PM (2010). Comparative phytochemical and antimicrobial screening of some solvent extracts of Samanea saman (fabaceae or mimosaceae) pods. Afr. J. Pure Appl. Chem. 4:206-212.

Oloyede GK, Onocha PA, Soyinka J, Oguntokun O, Thonda E (2010). Phytochemical Screening, Antimicrobial and Antioxidant activities of four Nigerian Medicinal Plants. Ann. Biol. Res. 1:114-120.

Ouattara F (2005). Traitement traditionnelle des infections sexuellement transmissibles au Mali: étude de la phytochimie et des activités biologiques des Annona senegalesis L. (Annonaceae) et de Stochytarpheta augustifolia Valh (Verbenaceae). Thesis, University of Bamako.

Rahman I (2008). Antioxidant therapeutic advances in COPD. Ther. Adv. Respir. Dis. 2:351-374.

Ram AJ, Bhakshu LM, Raju RRV (2004). In vitro antimicrobial activity of certain medicinal plants from eastern india, used for skin diseases. J. Ethnopharmacol. 90:353-357.

Scalbert A (1991). Antimicrobial proprieties of tannins. Phytochemistry 30:3875-3883.

Schmeda-Hirschmann G, Rodrıguez J, Theoduloz C, Astudillo S, Feresin G, Tapia A (2003). Free-radical scavengers and antioxidants from Peumus boldus Mol (Boldo). Free Radical Res. 37:447-452.

Shahat AA (2006). Procyanidins from Adansonia digitata. Pharm. Biol. 44:445-456.

Trichopoulou A, Soukara S, Vasilopoulou E (2007). Traditional foods: A science and society perspective. Trends Food Sci. Tech. 18:420-427.

Velazquez E, Tournier HA, Mordujovich de Bushiazzo P, Saavedra G, Schinella GR (2003). Antioxidant activity of Paraguayan plants extracts. Fitoterapia 74:91-97.

Vinson JA, Su X, Zubik L, Bose P (2001). Phenol antioxidant quantity and quality in foods: fruits. J. Agr. Food Chem. 49:5315-5321.

Wagner H, Blat S (2001). Plant drug analysis. Springer, $2^{\text {sd }}$ edition New York. pp 3, 53, 125, 149, 195, 263, 275, 281, 305 and 329.

Wolfe K, Wu X, Liu RH (2003). Antioxidant activity of apple peels. J. Agric. Food Chem. 51:609-614.

Wong CC, Li HB, Cheng K.W, Chen F (2006). A systematic survey of antioxidant activity of 30 Chinese medicinal plants using the ferric reducing antioxidant power assay. Food Chem. 4:705-711.

World health Organization (1998). The world health Report. Life in the 21 st Century: A vision for all 2. Measuring health. World Health Organization, Geneva, Switzerland, pp. 39-60.

Zakaria HM, Mainen JM, Pax JM, Modest CK, Ramadhani SON (2007). Antimicrobial activity and brine shrimp toxicity of extracts of Terminalia brownii roots and stem. BMC Complem. Altern. Med. 7:9. 